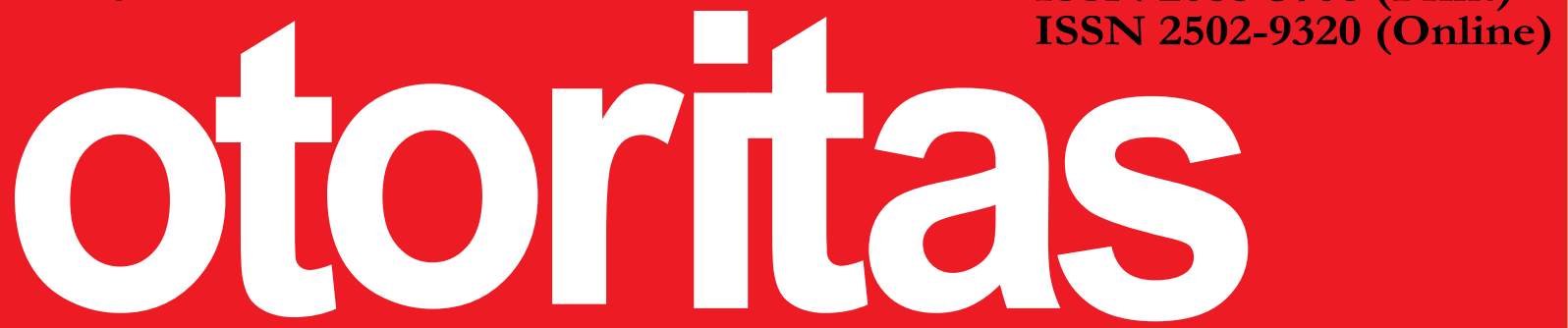

Jurnal IImu Pemerintahan

Building a Ukrainian Identity in Odessa: Negotiation of Markers and Informal Nationalism

Abel Polese

Discretion and Decentralization: Public Administrators

Dilemmas in Bureaucracy Innovation Initiatives

Lesmana Rian Andhika

The Women Representation Policy and its Effect to Women Political Participation in Jember, Indonesia

Ria Angin, Hary Yuswadi, Himawan Bayu Patriadi, Nur Dyah Gianawati

Sustainable Development Goals (SDGs) and Indonesian Housing Policy

Saddam Rassanjani

The Implementation of Minimum Service Standards (MMS) on Public Service for Health Services Sector in Bondowoso, Indonesia

Untung Kuzairi, Hary Yuswadi, Agus Budihardjo, Himawan Bayu Patriadi

Disaster Management Concept of Muhammadiyah Disaster Management Centre in Ponorogo, Indonesia

Yusuf Adam Hilman

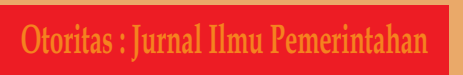

Volume 8

Issue 1

Page 1-81

Makassar, April 2018

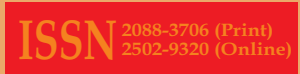

Program Studi Ilmu Pemerintahan Fakultas Ilmu Sosial dan Ilmu Politik Universitas Muhammadiyah Makassar

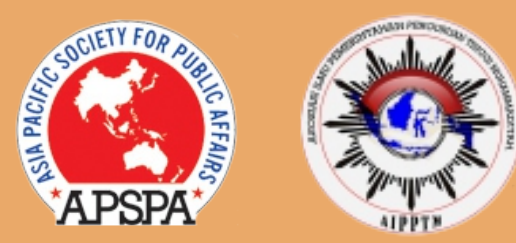


Available Online at http://journal.unismuh.ac.id/index.php/otoritas

Otoritas : Jurnal Ilmu Pemerintahan, 8 (1), April 2018, i

\section{Otoritas : Jurnal Ilmu Pemerintahan}

ISSN (Print): 2088-3706, ISSN (Online): 2502-9320

Volume 8 Issue 1 April 2018

\section{Editorial Team}

\section{Editor in Chief}

Ahmad Harakan, S.IP., M.HI

\section{International Editorial Board}

Farida Tadjine, Ph.D

Idil Akbar, S.IP., MA

Dr. Lukman Hakim, M.Si

Mergen Dyussenov, Ph.D

Prof. Madya Dr. Mohd. Afandi Salleh
Mubashar Hasan, Ph.D

Suyatno, Ph.D

Dr. Nuryanti Mustari, M.Si

Prof. Dr. Önder KUTLU

Assistant Editor

Hamrun, S.IP., M.Si

Muchlas M. Tahir, S.IP., M.Si

Muh. Firyal Akbar, S.IP., M.Si
Nurkhaerah, S.IP., M.IP

Zulfan Nahruddin, S.IP., M.Si

\section{International Peer Reviewer}

Abdul Hamid, Ph.D

Dr. Abdul Mahsyar, M.Si

Ali Muhammad, Ph.D

Prof. Dr. Achmad Nurmandi, M.Sc

Ahmad Rizky Mardhatillah Umar, S.IP., MA

Andi Luhur Prianto, S.IP., M.Si

Cahyo Seftyono, S.IP., MA

Dr. Dewi Kurniasih, M.Si

Eko Priyo Purnomo, Ph.D

Prof. Dr. Freedom C. Onuoha

Greg Lopez, Ph.D

Dr. Ihyani Malik, S.Sos., M.Si
Dr. Jaelan Usman, M.Si

Prof. Dr. Kamarulnizam Abdullah

Kittisak Jermsittiparsert, Ph.D

Dr. Muhlis Madani, M.Si

Ndubuisi Christian Ani, Ph.D

Prof. Dr. Rafael Gustavo Miranda Delgado

Prof. Dr. Riccardo Pelizzo

Prof. Rasim Özgür Dönmez, Ph.D

Simon Gray, Ph.D

Syahrul Hidayat, Ph.D

Prof. Dr. Steven Friedman

Wasisto Raharjo Jati, S.IP., MA

\footnotetext{
Published by

Program Studi Ilmu Pemerintahan Fakultas Ilmu Sosial dan Ilmu Politik Universitas Muhammadiyah Makassar in Collaboration with

Asosiasi Program Studi Ilmu Pemerintahan Perguruan Tinggi Muhammadiyah (AIPPTM) and

Asia Pacific Society for Public Affairs (APSPA)

Editorial Address

5th Floor of Iqra Building, Universitas Muhammadiyah Makassar Sultan Alauddin No.259, Makassar 90221, Indonesia Telp (0411) 866972, Email: otoritas@unismuh.ac.id https://www.gov-unismuh.ac.id
}

Otoritas : Jurnal Ilmu Pemerintahan published by Department of Governmental Science, Faculty of Social and Political Sciences Muhammadiyah University of Makassar in Collaboration with Muhammadiyah's College Association of Governmental Science (AIPPTM) and Asia Pacific Society for Public Affairs (APSPA). Published twice a year in April and October. This journal presents research results and articles relating to governmental issues. The editors invite you to submit articles according to the scientific writing format applicable for publication in this journal. 
Available Online at http://journal.unismuh.ac.id/index.php/otoritas

Otoritas : Jurnal Ilmu Pemerintahan, 8 (1), April 2018, ii

\section{Indexation}

Google Scholar

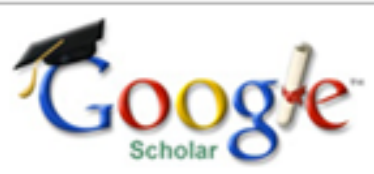

Indonesian Scientific Journal Database

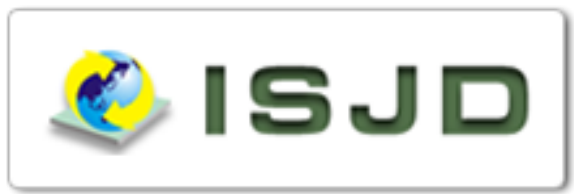

Indonesia One Search

\section{Sonesearch}

Directory of Open Access Journal

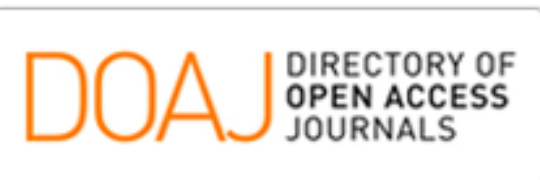

Science and Technology Index

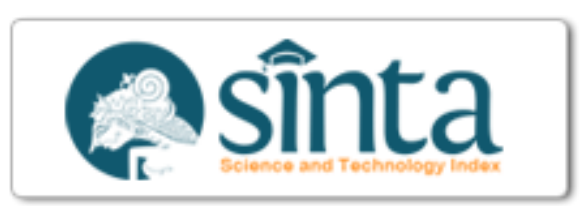

Bielefeld Academic Search Engine

\section{BASE}

Bielefeld Academic Search Engine

Indonesian Publication Index

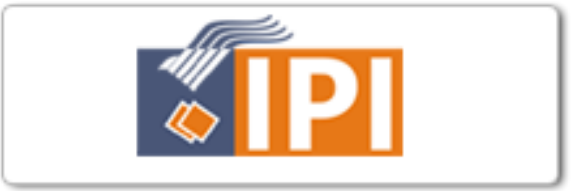

Public Knowledge Project Index

\section{PKP|INDEX}

WorldCat

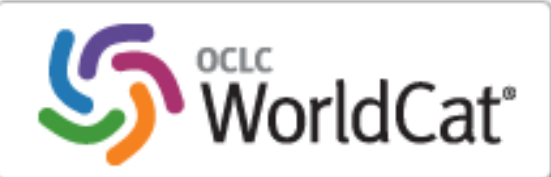

Crossref

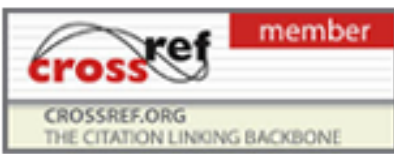


Available Online at http://journal.unismuh.ac.id/index.php/otoritas

Otoritas : Jurnal Ilmu Pemerintahan, 8 (1), April 2018, iii

\section{Table of Content}

$\begin{array}{ll}\text { Editorial Team } & \text { i }\end{array}$

$\begin{array}{ll}\text { Indexation } & \text { ii }\end{array}$

$\begin{array}{ll}\text { Table of Content } & \text { iii }\end{array}$

$\begin{array}{ll}\text { Preface } & \text { iv }\end{array}$

Building a Ukrainian Identity in Odessa: Negotiation of Markers and Informal Nationalism Abel Polese

Discretion and Decentralization: Public Administrators Dilemmas in Bureaucracy Innovation Initiatives

Lesmana Rian Andhika

The Women Representation Policy and its Effect to Women Political Participation in Jember, Indonesia

Ria Angin, Hary Yuswadi, Himawan Bayu Patriadi, Nur Dyah Gianawati

Sustainable Development Goals (SDGs) and Indonesian Housing Policy

Saddam Rassanjani

The Implementation of Minimum Service Standards (MMS) on Public Service for Health Services Sector in Bondowoso, Indonesia

Untung Kuzairi, Hary Yuswadi, Agus Budihardjo, Himawan Bayu Patriadi

Disaster Management Concept of Muhammadiyah Disaster Management Centre in Ponorogo, Indonesia

Yusuf Adam Hilman

Author Guidelines

Publication Ethics and Malpractice Statement 
Available Online at http://journal.unismuh.ac.id/index.php/otoritas

Otoritas : Jurnal Ilmu Pemerintahan, 8 (1), April 2018, iv

\section{Preface}

\section{Assalamu Alaikum Warahmatullahi Wabarakatuh.}

Praise be to the Lord, we are grateful to publish volume 8 issue 1 April 2018. In this issue six papers are published with the total number of 81 pages. The authors came from United Kingdom, Estonia and Indonesia.

The articles of this issues discuss about the concept of disaster management, nationalism in Ukraine, the SDGs program, women's representation in Parliament, public administrators, and public service in the health sector. Hopefully for the next issue, we will strive to improve the quality of the rticles and make the selection of more restrictive articles so that the dissemination of insights and actual studies in the field of government and related issues can be well organized.

Wassalamu Alaikum Warahmatullahi Wabarakatuh.

Editor in Chief

Ahmad Harakan, S.IP., M.HI 